\title{
Current Status Towards 90-90-90 UNAIDS Target and Factors Associated with HIV Viral Load Suppression in Kediri City, Indonesia
}

This article was published in the following Dove Press journal: HIVIAIDS - Research and Palliative Care

\author{
Geofrey Ssekalembe (D) \\ Muhammad Atoillah \\ Isfandiari (iD) \\ Hendick Suprianto ${ }^{2}$ \\ 'Faculty of Public Health, Universitas \\ Airlangga, Surabaya, Indonesia; ${ }^{2}$ Dinas \\ Kesehatan Kota Kediri, Kediri, Indonesia
}

Introduction: In 2016, UN Member States committed to reduce new HIV infections to fewer than 500,000 annually by 2020 , a $75 \%$ reduction compared with 2010 , reduce AIDS-related deaths to fewer than 500,000 globally as a means of ending AIDS by 2030. The UNAIDS 2020 target is to have $90 \%$ of the people living with HIV know their status, $90 \%$ of the people living with HIV (who know their HIV status as positive) are already on ART treatment, $90 \%$ of people on treatment are virally suppressed. The objective of this study is to determine the current status towards the 2020 90-9-90 UNAIDS target and the factors associated with HIV viral load suppression in Kediri city.

Methods: The study was a cross-sectional study in Kediri city. The researcher collected secondary data, carried in-depth interviews, then determined the percentage of HIV-positive patients that did a HIV test and received their results as Positive, the percentage of HIVpositive patients that started ART treatment, the percentage of HIV-positive patients that have viral load suppression from the viral load tests done. A simple bivariate logistic and multivariate logistic regression was used to determine the significant factors that determine viral suppression.

Results: The progress towards the $90-90-90$ UNAIDS target was at $6.4 \%, 74.9 \%, 9.9 \%$. The time taken by the HIV-positive patient to start ART treatment from the time of confirmation of HIV positive $(\mathrm{AOR}=83.191, \mathrm{CI}: 1.617-4280.115)$ and decrease in body weight of the patient $(A O R=29.636, C I: 1.193-736.167)$ were found to significantly influence viral load suppression.

Conclusion: There is a need to scale up HIV case-detection capacity through creating awareness about HIV, HIV testing and counselling and expand the ART services so as to achieve the 90-0-90 UNAIDS target. Early initiation to ART treatment (Test and Treat) and encouraging body gaining behaviors are needed to achieve viral load suppression.

Keywords: AIDS, ART, HIV, suppression, viral, Kediri

\section{Introduction}

HIV still remains a major public health threat with over 35 million deaths and counting, and in 2016, there were still over two million infections. ${ }^{1}$ However HIV treatment can dramatically extend the lifespan of people living with HIV and effectively prevent HIV transmission. ${ }^{2}$ In 2016, United Nations Member States committed to reduce new HIV infections to fewer than 500,000 annually by 2020 , a $75 \%$ reduction compared with 2010, reduce AIDS-related deaths to fewer than 500000 globally, eliminate HIVrelated stigma and discrimination and ending AIDS as a public health threat by $2030 .{ }^{3,4}$
Correspondence: Geofrey Ssekalemb Faculty of Public Health, Universitas Airlangga, Mulyorejo, Surabaya 60II5 Indonesia

Email gsekalembe@gmail.com 
The discovery of effective treatment with antiretroviral therapy (ART) in 1996 and subsequent evidence regarding the prevention of illness, death and transmission transformed the epidemic from an unending, unmitigated disaster into something that could be prevented and even ended. ${ }^{5}$ Of recent, UNAIDS updated the 2030 sustainable Development Goals (SDGs) to achieve a new 95-95-95 HIV treatment and have less than 200,000 new HIV infections. ${ }^{6,7}$ However, the main 2020 target for UNAIDS is to ensure that $90 \%$ of the people living with HIV know their status, $90 \%$ of the people living with HIV (who know their HIV status as positive) are already on ART treatment, $90 \%$ of people on treatment are virally suppressed. ${ }^{8}$ Attaining this target would mean that, by 2020 , $73 \%$ of all people living with HIV will have suppressed viral loads. 9 Data from 146 countries show that some have achieved declines in new HIV infections among adults of $50 \%$ or more over the last 10 years, while many others have not made measurable progress, and yet others have experienced worrying increases in new HIV infections. ${ }^{10}$ Asia and the Pacific are expected to experience almost 480,000 new HIV infections in 2030 if coverage remains at 2013 levels, compared to fewer than 97,000 infections under the 90-90-90 Fast-Track response. $^{2}$

In 2015, of the 36.7 million people living with HIV globally, an estimated $60 \%$ knew their HIV status, $46 \%$ were on antiretroviral therapy, and $38 \%$ had achieved viral suppression. $^{10}$ In 2015, more than 14.5 million of the 36.7 million (43\%) people living with HIV do not know their HIV status. About $54 \%$ of the people living with HIV have not yet started Antiretroviral treatment and only an estimated $38 \%$ of people living with HIV worldwide are virally suppressed. ${ }^{10}$ Of late, globally, there 37.9 million people having HIV by 2018 and 23.3 million where already accessing ART treatment (62\%). ${ }^{11}$ In the Asia and the pacific region, 5.9 million were estimated to be having HIV of which 3.2 million where accessing ART treatment by 2018. ${ }^{11}$ In 2017, East Java (Jawa Timur) had the highest number of HIV cases in Indonesia. ${ }^{12}$ For the first time in 2017, the number of people living with HIV accessing treatment exceeded the number of people not yet n treatment. ${ }^{13}$ By 2018, about 8.1 million people did not know that they were living with HIV. ${ }^{11}$ In 2018, According to UNAIDS 909090 target by 2020, 75\% of people living with HIV knew their status (approximately three out of four people), 79\% of them (approximately four out of five HIV positive patients that knew their status) were accessing treatment and among those accessing treatment, $81 \%$ (approximately four out of five HIV positive patients that had started ART treatment) were virally suppressed. ${ }^{11}$ Of all people living with HIV, 79\% knew their status, $62 \%$ were accessing treatment and 53\% were virally suppressed in $2018 .^{14}$

Indonesia being among the thirty-five countries accounting for more than $90 \%$ of the people becoming newly infected with HIV has been designated Fast-Track countries, it requires intensive action to mitigate the epidemic. ${ }^{4}$ In the Asia and the Pacific region, 5 million people were living with HIV in 2014, of which Indonesia was among the top six countries that have $90 \%$ of the burden. ${ }^{1}$ China, India and Indonesia are among the UNAIDS FastTrack countries and account for 78\% of people newly infected with HIV in the region. ${ }^{1}$ The number of people with HIV/AIDS at the age of $\geq 15$ years in Indonesia was estimated and projected to reach 628,492 people in 2017, with the number of new infections as many as 46,357 people and mortality of 40,468 people (Estimation and Projection of HIV/AIDS in Indonesia for the period of 2015-2020, Ministry of Health RI). ${ }^{15}$ According to UNAIDS, Surabaya and Jakarta are among the cities that account for 1.1 million people living with HIV. ${ }^{1}$

Prevention of the HIV epidemic has continued to lag because $40 \%$ of people living with HIV do not know their HIV status and $62 \%$ of people living with HIV are not virally suppressed making it hard to achieve the 90-90-90 target. ${ }^{10}$ In other words, nearly two-thirds of people living with HIV could transmit the virus unless they are provided with prevention tools and empowered to use them. ${ }^{10}$ The likelihood of transmitting HIV from a person living with HIV who is on antiretroviral therapy (ART) and has achieved a suppressed HIV viral load in his/her blood for at least 6 months is extremely low (negligible. ${ }^{16-18}$

The ASEAN zero project Declaration Initiative has Indonesia as the leading country to ensure no new HIV Infection, no Discrimination of HIV patients, and no more deaths related to AIDS in all ASEAN cities was adopted by ASEAN Leaders at the 19th Summit on November 17, 2011, in Bali, Indonesia. ${ }^{19}$ In Asia and the pacific, HIV exists more in the Key populations. HIV cascade data among key populations in Indonesia show very poor rates of retention in treatment and viral suppression. ${ }^{20}$ Site and individual characteristics associated with initiating and continuing treatment suggest an urgent need to develop and implement effective interventions to support patients in achieving viral suppression among all people with HIV. ${ }^{20}$ 
The continued expansion of ART and support for sustainable viral suppression will make it possible to significantly reduce transmission and eliminate HIV in the general public. ${ }^{17,21-23}$ In PLHIV, viral load (expressed as HIV RNA copies $/ \mathrm{mL}$ of blood) is a direct indicator of viral replication. ${ }^{24}$ Viral load tests prevent patients being unnecessarily switched to more expensive medicines or left to continue on ineffective therapy that can lead to drug resistance and ultimately death. World Health Organization (WHO) recommends viral load testing to be the preferred monitoring tool for diagnosing and confirming antiretroviral therapy failure. ${ }^{25,26}$

Recent studies have shown that a number of factors influence viral load suppression among HIV-positive patients. Among them include age, sex, marital status, level of education, level of employment, entry point, tuberculosis status, duration on ART, ART regimen, adherence, first viral load result. ${ }^{24,27-29}$ Strong adherence to antiretroviral therapy suppresses viral load to undetectable levels within people living with HIV, greatly reducing the risk of transmitting the virus to others. ${ }^{5,16,30}$ Timely initiation of treatment and sustained engagement in HIV care are important to achieving viral load suppression, which is a key marker for successful treatment. ${ }^{31,32}$ Since $\mathrm{Tb}$ is the leading cause of death among people living in AIDS, all people living with TB should have access to HIV testing and antiretroviral therapy. ${ }^{13}$

As we come closer to 2020 , there was a need to assess the progress of Kediri city towards the UNAIDS 90-90-90 target. The aim of the study was to determine the current status toward the UNAIDS $90-90-90$ target, that $90 \%$ of the people living with HIV know their status, $90 \%$ of the people living with HIV (who know their HIV status as positive) are already on ART treatment, $90 \%$ of people on treatment are virally suppressed and also to analyze the factors that determine viral load suppression among HIV patients that are on care in Kediri city.

\section{Methods of Study}

\section{Data Collection}

The study was a cross-sectional analytic (Quantitative) study in Kediri city in East Java of Indonesia. In Kediri city, there are nine health centers of which only 4 have ART treatment services and one of the four health centers has just started 4 months before the study was done and there no HIV patient at this health center had taken any viral load test. The researcher, therefore, collected data from three health centers: Gambiran general hospital,
Pesantren I health center and Semampir health center and also carried in-depth interviews on two key informants; the Health worker that works on HIV patients in the HIV unit at Pesantren 1 health center, a member of the Peer Support Group in Kediri city to determine the reasons behind the results/findings.

The researcher also collected the total number of patients that have visited the health centers, total number of patients that were referred to the HIV units to do a HIV test, total number of patients that actually did the HIV test and received their results and where positive, total number of patients that started Pre ART and ART treatment, total number of patients that have at least one successful viral load test. The researcher then determined the percentage of HIV-positive patients that did a HIV test and received their results as Positive, the percentage of HIV-positive patients that started ART treatment, the percentage of HIV-positive patients that have viral load suppression from the viral load tests done. Viral load suppression was recorded if there are less than 40 copies of the virus per milliliter. ${ }^{23}$ Patients that were referred to the HIV unit to take a HIV test were always first assessed by the health workers in the various units in the health center to have risk factors of a patient who might have HIV. These factors included Tuberculosis, Diarrhea, syphilis, Gonorrhea and other sexually transmitted infections (STIs).

The researcher thereafter collected a random sample of HIV patients that have at least had a single viral load test and had a successful viral load test to analyze the factors associated with viral load suppression in Kediri city. A sample size of 75 patients was determined using the WHO estimates for sample size calculation under Table $9 \mathrm{~h}$ which determines an appropriate sample size that estimates the Odd ratio to within $50 \%$ of the true OR with $95 \%$ confidence $($ expected Odd ratio $=2.50, \mathrm{P} * 2=0.25) .{ }^{33}$

\section{Data Analysis}

The researcher then calculated the three 90 targets (percentage of HIV-positive patients that did a HIV test and received their results as Positive, percentage of HIVpositive patients that started ART treatment, percentage of HIV-positive patients that are on ART treatment and have viral load suppression from the last viral load test done) according to the 2018 UNAIDS Global AIDS Monitoring indicators. ${ }^{34,35}$ Viral load suppression was recorded if there are less than 40 copies of the virus per milliliter. $^{23}$ 
The researcher analyzed the descriptive statistics of all the HIV-positive patients that are on ART treatment at the health center. The demographics analyzed included; Age, sex, marital status, level of education, level of employment, entry point, tuberculosis status, years of ART initiation, adherence, follow-up status (Death, lost, transfer out, followed up, due for follow-up, active), viral load test, viral load result. A viral load test measures the number of HIV viral particles per millilitre of blood. ${ }^{9}$

The researcher analyzed using the bivariate analysis to determine the significant factors that may determine viral suppression among the HIV-positive patients that are already on ART treatment. The factors analyzed include Gender, marital status, level of education, level of employment, risk factor, time taken to take the first load test, tuberculosis status, time taken to start ART treatment from the time of confirmation of HIV positive, Adherence, regiment (First line, second line or third line), WHO clinical status. However, in determining the relationship of the independent factors to influence viral load suppression, the researcher restricted the analysis to those who had at least one viral load testing. The researcher used a Pearson chi-square analysis for determining the significance of the relationship of the: Gender, marital status, level of education, level of employment, risk factor status, tuberculosis status, adherence, ART regimen (First line, second line or third line), WHO clinical status to viral load suppression, change in body weight while on ART and one way ANOVA to determine the significance of the relationship of age, time taken to start ART treatment from the time of confirmation of HIV positive and time taken to take the first load test to achieve viral load suppression. Then, later a binary logistic regression was run for the significant variables to determine how they influence viral load suppression. Data were analyzed in Microsoft Excel and Stata 14.2 (Stata Corps, STATA 14 Software)

\section{Results}

The progress of Kediri city towards the 90-90-90 UNAIDS target in 2020 is summarized in Table 1 and Figure 1.

Figure 1 shows that $6.4 \%$ of the total number of patients that were counseled and tested were HIV positive. Of the 136 patients that are on HIV care at the health center, $74.9 \%$ have already started ART treatment. Of the 805 HIV-positive patients that are on ART treatment, only 122 have at least taken one viral load test and 9.9\% (80 out of 805) of the total patients on ART have suppressed viral
Table I Towards the $90-90-90$ UNAIDS Target

\begin{tabular}{|l|l|l|}
\hline Data Collected & N & $\%$ \\
\hline Patients referred to the HIV Unit for HIV testing & 16,674 & \\
Patients confirmed Positive at the HIV Unit & 1075 & $6.4 \%$ \\
HIV positive patients enrolled on HIV care & 1075 & \\
HIV positive patients enrolled on Pre ART & 270 & \\
HIV positive patients enrolled on ART & 805 & $74.9 \%$ \\
ART patients that have had a viral load test & 122 & $15.2 \%$ \\
ART patients that have had suppressed VL results & 80 & $9.9 \%$ \\
\hline
\end{tabular}

loads though $65.6 \%$ ( 80 out of 122) of those that took a viral load test have suppressed viral load results.

Summary statistics of the continuous variables (Table 2) and frequencies of the categorical variable was done on all the potential factors that could influence viral load suppression among HIV-positive patients. A simple bivariate logistic analysis was done to determine the crude odd ratios and the results (Table 3 ) to determine their direct influence on viral load suppression. Later, a multivariate binary logistic regression was done to determine how the associated factors influence viral load suppression (Table 3). All levels of significance were compared at $95 \%$.

The results from the multivariate logistic analysis (Table 3) below showed that the patients that took more than 1 year to start ART treatment are significantly more likely $(\mathrm{P}<0.05$, odds ratio $=83.191>1,95 \% \mathrm{CI}$ : $1.617-4280.115)$ to have a viral load non-suppression as compared to the patients that start ART treatment in less than 1 month. The results also showed patients with a decrease in body weight from the start or ART treatment to the current body weight while on weight are significantly more likely $(\mathrm{P}<0.05$, odds ratio $=29.636>1,95 \% \mathrm{CI}$ : 1.193-736.167) to have non-suppressed viral load results as compared to patient that have no change in body weight.

\section{Discussion}

There are several factors associated with achieving each of the 90-90-90 targets. Reaching the first target will require efforts to increase the uptake of HIV testing by addressing issues such as tapping much into HIV testing of Key populations, risk perception, accessibility of services, community knowledge and awareness. The health workers only refer a few selected patients that visit the health center for HIV counselling and testing. A patient is referred to have a HIV test if he has signs of Tuberculosis, Diarrhea, Hepatitis, oral ovagial candidiasis, dermatitis, herpes, toxoplasmosis, wasting syndrome, pneumocystis Carinii 


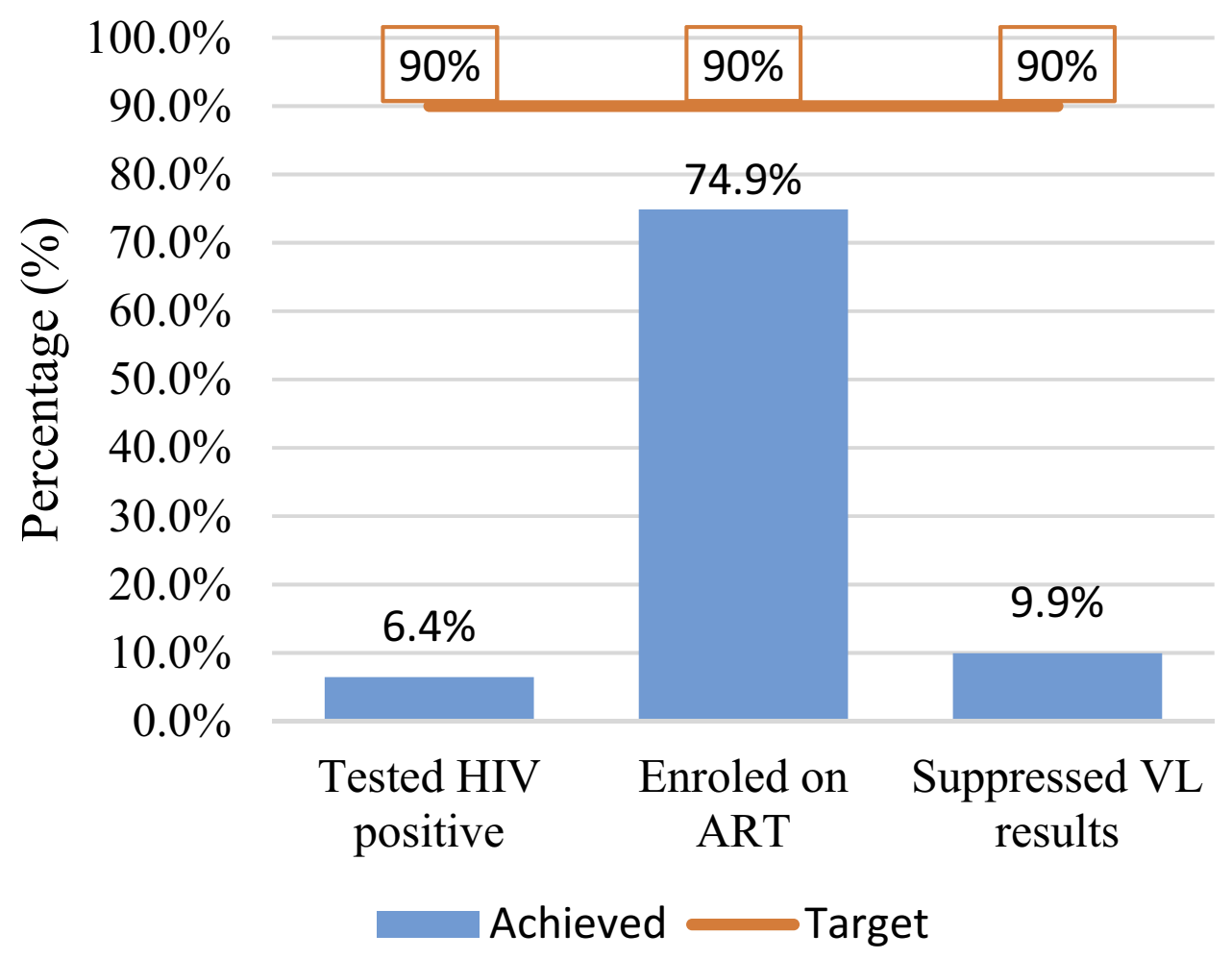

Figure I The progress towards $90-90-90$ UNAIDS target.

Pneumonia, Leukocytogenic Leukocytogenesis Vasculitis and other sexually transmitted infections such as Syphilis, Gonorrhea, among others. This has limited the number of patients infected with HIV to be tested hence having a percentage that far away from the $90 \%$ target at just only $6.4 \%$ HIV-positive patients. Globally, $40 \%$ of people living with HIV (19 million) are not aware of their HIVpositive status and therefore HIV testing HIV should be encouraged and supported through self-testing and community-based testing so as to reach people in diverse settings outside health facilities, especially key populations and men. ${ }^{4}$

Table 2 Summary Statistics for Continuous Variables

\begin{tabular}{|l|l|l|l|l|}
\hline Continuous Variables & Mean & Minimum & Median & Maximum \\
\hline $\begin{array}{l}\text { Age of the patient at ART } \\
\text { Induction (years) }\end{array}$ & 34 & 18 & 33 & 60 \\
\hline $\begin{array}{l}\text { Time taken to start ART } \\
\text { (days) }\end{array}$ & 152 & 0 & 58 & 2,05 \\
\hline $\begin{array}{l}\text { Body weight at start of } \\
\text { ART (Kg) }\end{array}$ & 55.7 & 26 & 57 & 80 \\
\hline Current weight at ART (Kg) & 58.4 & 34 & 58 & 82 \\
\hline $\begin{array}{l}\text { Time taken to do the first } \\
\text { viral load test (months) }\end{array}$ & 31 & 12 & 23 & 86 \\
\hline
\end{tabular}

The estimate of the second 90-90-90 target is the highest of the three targets. This mainly attributed to the WHO recommendation of Test and Treat approach in that ART should be initiated in all people living with HIV (HIV exposed infants less than 10 years, adolescents between 10 and 19 years, adults above 19 years and pregnant women living with HIV) regardless of their WHO clinical stage and CD4 count, ${ }^{26}$ proper administration of ART therapy through the 4S (Start, Substitute, Switch and STOP) ART medicine being free and it takes much ease for both the health center and patients to easily coordinate and start ART treatment. Shifts toward earlier initiation of treatment, simplified and more tolerable regimens, and adherence support interventions like a peer support group have influenced initiation and uptake of ART treatment. This largely contributed to the second 90-90-90 target to $74.9 \%$. However, even nationally, ART treatment of HIV patients is still very low, for example, in 2016, only $32.1 \%(69,954$ of the $217,631 \mathrm{HIV}$ patients) were receiving ART therapy. ${ }^{36}$

On starting treatment, many patients remain engaged in HIV care and have follow-up services to monitor the effectiveness of the treatment. However, less have taken a viral load test since their initiation on ART treatment. This has been attributed to the fact that viral load testing is not free at this health center. This largely explains why the estimate of the 
Table 3 Descriptive Statistics of Categorical Independent Variables and Binary Logistic Regression versus Viral Load Suppression

\begin{tabular}{|c|c|c|c|c|c|c|c|}
\hline Viral Load Result & $\begin{array}{l}\text { Suppressed } \\
\text { (48) }\end{array}$ & $\begin{array}{l}\text { Non } \\
\text { Suppressed } \\
\text { (27) }\end{array}$ & $\begin{array}{l}\text { Crude Odd } \\
\text { Ratio (COR) }\end{array}$ & $P$ value & $\begin{array}{l}\text { Adjusted Odd } \\
\text { Ratio (AOR) }\end{array}$ & $\begin{array}{l}95 \% \mathrm{Cl} \text { (for } \\
\text { AOR) }\end{array}$ & $P$ value \\
\hline \multicolumn{8}{|c|}{ Age at ART induction category (Years) } \\
\hline Less than 20 & $6(12.5)$ & I (3.70) & I & - & 1 & - & \\
\hline $21-35$ & $21(43.8)$ & $16(59.3)$ & 4.571 & 0.179 & 218.776 & $0.945-50,662.9$ & 0.052 \\
\hline $36-55$ & $21(43.8)$ & $8(29.6)$ & 2.286 & $0.47 \mathrm{I}$ & 90.269 & $0.596-13,663.77$ & 0.079 \\
\hline Above 55 & 0 & $2(7.4)$ & 1 & - & 1 & I & - \\
\hline \multicolumn{8}{|c|}{ Time taken to start ART since confirming HIV positive } \\
\hline Less than one month & I8 (37.5) & $5(\mid 8.5)$ & I & - & 1 & - & \\
\hline I-6 months & $25(52.1)$ & $17(63.0)$ & 2.448 & 0.133 & 5.358 & $0.718-40.006$ & 0.102 \\
\hline $6-12$ months & $2(4.2)$ & I (3.7) & 1.800 & 0.657 & 1.346 & $0.017-108.466$ & 0.895 \\
\hline More than I year & $3(6.3)$ & $4(14.8)$ & 4.800 & 0.087 & 83.191 & $1.617-4280.115$ & 0.028 \\
\hline \multicolumn{8}{|c|}{ Time taken to do a viral load test since starting ART treatment } \\
\hline $1-12$ months & $\mathrm{I}(2.1)$ & 0 & I & - & I & - & - \\
\hline 13-24 months & $22(45.8)$ & $17(63.0)$ & 3.091 & 0.800 & 3.091 & $0.094-161-930$ & 0.473 \\
\hline $25-36$ months & $9(18.8)$ & $6(22.2)$ & 2.667 & 0.202 & 6.581 & $0.223-194.474$ & 0.275 \\
\hline More than 36 months* & $16(33.3)$ & $4(14.8)$ & 1 & - & 1 & - & - \\
\hline \multicolumn{8}{|l|}{ Marital status } \\
\hline Married & $9(18.8)$ & $6(22.2)$ & 1 & - & I & - & \\
\hline Single & $24(50.0)$ & $12(44.4)$ & 0.750 & 0.650 & 0.554 & $0.113-27.050$ & 0.766 \\
\hline Widow/widower & I5 (31.2) & $9(33.3)$ & 0.900 & 0.876 & 0.523 & $0.030-9.099$ & 0.657 \\
\hline \multicolumn{8}{|l|}{ Gender } \\
\hline Male & $31(64.6)$ & $19(70.4)$ & $\mathrm{I}$ & - & 1 & - & - \\
\hline Female & $17(35.4)$ & $8(29.6)$ & 0.768 & 0.610 & 0.717 & $0.078-6.567$ & 0.769 \\
\hline \multicolumn{8}{|l|}{ Entry point } \\
\hline Maternal and Child Health & I (2.I) & 0 & I & - & 1 & - & - \\
\hline Outpatient & $10(20.8)$ & $8(30.0)$ & 4.8 & 0.184 & 4.979 & $0.159-155.591$ & 0.361 \\
\hline Inpatient & $10(20.8)$ & $9(33.3)$ & 5.4 & 0.151 & 8.395 & $0.09 \mid-777.988$ & 0.357 \\
\hline Private practice* & I (2.I) & 0 & I & - & 1 & - & - \\
\hline Key population (IDU, & $9(18.8)$ & $4(14.8)$ & 2.667 & 0.79 & 6.760 & $0.194-235.302$ & 0.292 \\
\hline MSM, sex workers & & & & & & & \\
\hline NGO & II (23.0) & $5(18.5)$ & 2.727 & 0.83 & 10.367 & $0.344-312.776$ & 0.178 \\
\hline Self-referral* & $6(12.5)$ & I (3.7) & 1 & - & 1 & - & - \\
\hline \multicolumn{8}{|l|}{ Education level } \\
\hline No education & $I(2.1)$ & 0 & 1 & - & 1 & - & - \\
\hline Primary school & $3(6.3)$ & $2(7.4)$ & 0.933 & 0.949 & 1.149 & $0.021-62.208$ & 0.946 \\
\hline Junior school (SMP) & $3(6.3)$ & $4(14.8)$ & 1.867 & 0.517 & 31.863 & $0.706-1438-853$ & 0.075 \\
\hline High school (SMA) & $34(70.83)$ & $16(59.3)$ & 0.659 & 0.527 & 2.786 & $0.225-34.533$ & 0.425 \\
\hline College/University* & $7(14.6)$ & $5(I 8.5)$ & 1 & - & 1 & - & - \\
\hline \multicolumn{8}{|l|}{ Employment status } \\
\hline Not working & $6(12.5)$ & $4(14.8 I)$ & 1 & - & I & - & - \\
\hline Working & $42(87.5)$ & $23(85.2)$ & 0.821 & 0.777 & 0.239 & $0.0116-4.942$ & 0.354 \\
\hline
\end{tabular}


Table 3 (Continued).

\begin{tabular}{|c|c|c|c|c|c|c|c|}
\hline Viral Load Result & $\begin{array}{l}\text { Suppressed } \\
\text { (48) }\end{array}$ & $\begin{array}{l}\text { Non } \\
\text { Suppressed } \\
\text { (27) }\end{array}$ & $\begin{array}{l}\text { Crude Odd } \\
\text { Ratio (COR) }\end{array}$ & P value & $\begin{array}{l}\text { Adjusted Odd } \\
\text { Ratio (AOR) }\end{array}$ & $\begin{array}{l}95 \% \mathrm{Cl} \text { (for } \\
\text { AOR) }\end{array}$ & $P$ value \\
\hline \multicolumn{8}{|l|}{ Risk factor } \\
\hline Heterosexual & $28(58.3)$ & $14(5 \mid .9)$ & I & - & 1 & - & \\
\hline Homosexual & $19(39.6)$ & $13(48.2)$ & 1.368 & 0.519 & 5.056 & $0.147-173.801$ & 0.369 \\
\hline Perinatal* & $I(2.1)$ & 0 & 1 & - & 1 & - & - \\
\hline \multicolumn{8}{|c|}{ WHO standard status while on ART } \\
\hline Asymptotic & $17(35.4)$ & $7(26.0)$ & I & - & 1 & - & \\
\hline Mild symptoms & II (23.0) & $5(18.5)$ & 1.104 & 0.888 & 3.456 & $0 .|3|-9|.04|$ & 0.457 \\
\hline Moderate symptoms & $18(37.5)$ & $13(48.2)$ & 1.754 & 0.331 & 1.253 & $0.128-12.237$ & 0.846 \\
\hline AIDS & $2(4.2)$ & $2(7.4)$ & 2.429 & 0.418 & 18.636 & $0.157-2209.577$ & 0.230 \\
\hline \multicolumn{8}{|c|}{ Change in body weight while on ART } \\
\hline No change & $15(3 \mid .3)$ & $3(I I . I)$ & I & - & I & - & - \\
\hline Decrease & $6(12.5)$ & $6(22.2)$ & 5.000 & 0.60 & 29.636 & $1.193-736.167$ & 0.039 \\
\hline Increase & $27(56.3)$ & $18(66.7)$ & 3.333 & 0.086 & 2.878 & $0.212-39.113$ & 0.427 \\
\hline \multicolumn{8}{|c|}{ WHO standard status while on pre ART } \\
\hline Asymptotic & $23(48.0)$ & $15(55.6)$ & 1 & - & 1 & - & - \\
\hline Mild symptoms & $6(12.5)$ & $3(I I . I)$ & 0.7667 & 0.734 & 1.251 & $0.052-30.064$ & 0.890 \\
\hline Moderate symptoms & $15(31.3)$ & $7(26.0)$ & 0.716 & 0.553 & 0.473 & $0.024-9.486$ & 0.624 \\
\hline AIDS & $4(8.3)$ & $2(7.4)$ & 0.767 & 0.775 & 0.030 & $0.000-2.052$ & 0.104 \\
\hline
\end{tabular}

Notes: *Variables were found to be collinear with the reference variable.

third 90-90-90 target is very low, same as the whole country at large. The cost and complexity of ART treatment and Viral Load testing technologies also limit their availability. Same case in Indonesia, viral load tests in a few selected central laboratories. ${ }^{9}$ It also explains more why no patient has more than one viral load result. The nearest viral load testing place is located in Surabaya at DR. Soetomo Hospital which is far away from Kediri city making it more costly to do the viral load test. It may also be attributed to the fact that most HIV patients feel healthy and do not feel like doing a viral load test as reported by one of the members of the peer support group in this region.

We observed the patients on ART treatment and have at least one viral load test took an average of 31 months to their first viral load test. WHO recommends viral load monitoring 6 months after initiating antiretroviral therapy and thereafter 12 months annually for people who are virally suppressed. ${ }^{26,37}$ There is a need to scale up Viral load testing to assess regimen response as a way to improve the substitution, switching to second and third regimens or no change in ART regimen. ${ }^{38}$ In people for whom viral load tests suggest treatment failure, WHO recommends enhanced adherence counselling, followed by an additional viral load test to establish re-suppression or to confirm treatment failure and a switch to an alternative regimen. ${ }^{37}$ This all sums up the need to do timely viral load testing so as to determine the treatment response, alternative treatment options.

To achieve the 2020 UNAIDS 90-90-90 targets, it will require prioritizing viral load-oriented care to ensure optimal HIV clinical follow-up, adherence and resistance monitoring. ${ }^{39}$ However, as earlier noted in earlier studies, data on viral load suppression are not readily available in most provinces in Indonesia making it hard to assess the progress of ART treatment. ${ }^{40}$ According to Granich, ${ }^{21}$ an increase in the number of people diagnosed and initiated on treatment will normalize the HIV epidemic and also encourage others to seek testing and treatment hence achieving the UNAIDS 90-90-90 target. As suggested by, ${ }^{41}$ there is a need to scale up HIV case-detection capacity through creating awareness about HIV, HIV testing and counselling (HTC), reducing stigma and discrimination and also need to expand the ART services so as to achieve the 90-90-90 UNAIDS target. 
On analyzing the factors that determine viral load suppression among HIV-positive patients that are already on ART treatment and have at least taken one viral load test, the time taken by the HIV-positive patient to start ART treatment from the time of confirmation being HIV positive and a decrease in body weight were found to significantly negatively influence viral load suppression in HIV-positive patients. The time taken (more than 1 year) by the HIVpositive patient to start ART treatment from the time of confirmation being HIV positive was found to significantly influence viral load suppression in HIV-positive patients and was consistent with previous studies like. ${ }^{42}$ We observed that the average time of time taken to start ART treatment from the time of confirmation of HIV-positive status was 152 days (5 months). WHO recommends immediate initiation (Test and Treat) of all confirmed HIV-positive patients on ART treatment. ${ }^{26,43}$ The earlier the better. Early initiation to ART treatment after confirmation of HIV positive improves morbidity and mortality in all stages of HIV infection. ${ }^{22,44-46}$ Early initiation of ART treatment reduces HIV transmission since it reduces the plasma HIV levels. ${ }^{47}$ Previous studies also suggest that earlier initiation of ART increases the potential to identify patients at risk of poor viral load suppression. ${ }^{48}$

An increase in body weight can predict better immune reconstitution in HIV-infected patients after highly active antiretroviral therapy HAART initiating. ${ }^{49}$ HIV-positive patients who are losing weight and are not taking HAART should always be considered for HAART and this is a clear sign that they are most likely to have non-suppressed viral loads. ${ }^{50}$ HIV-positive patients with a higher Body Mass Index (BMI) than the normal are longitudinally associated with improved immunological health. ${ }^{51}$

It is also important to note that the mean time of the HIV patients that are on ART treatment to do their first viral load test was 31 months, a big difference from the WHO and UNAIDS recommendations to have the first viral load test 6 months after initiation on ART. Only $15.2 \%$ of the HIV patients on ART had taken a single viral load test. WHO recommends viral load monitoring 6 months after initiating antiretroviral therapy and thereafter 12 months annually for people who are virally suppressed. ${ }^{26,37}$ There is a need to scale up Viral load testing to assess regimen response as a way to improve the substitution, switching to second and third regimens or no change in ART regimen. ${ }^{38}$ For HIV patients whose viral load results are non-suppressed, WHO recommends enhanced/intensive adherence counselling for 3 consecutive months, followed by a viral load test after the third month to establish re-suppression or to confirm treatment failure and a switch to an alternative regimen. ${ }^{37}$ This all sums up the need to do timely viral load testing so as to determine the treatment response so as to consider alternative treatment options.

However, social conditions related to poverty, limited viral load testing points, lack of access to support services can decrease the degree to which individuals remain engaged in care. Issues related to privacy and stigma may also impede access to and retention in care. Therefore, it is important to continue to work towards creating supportive environments that address social determinants, decrease stigma and discrimination, and reduce barriers to prevention, treatment, care and support. It is still worrying that achieving the 909090 by 2020 targets will still leave $27 \%$ of people living with HIV with unsuppressed viral loads in 2020, so expanded investments in proven HIV prevention strategies will be critical to hopes for ending the AIDS epidemic. ${ }^{2}$

The major strength of this study was that it was the first study to determine progress towards the 2020 90-90-90 UNAIDS target and also conclude that the time taken by the HIV-positive patient to start ART treatment from the time of confirmation of HIV positive and the time taken by the HIV-positive patient to take the first viral load test from the time when this patient started ART treatment were significant factors to influence viral load suppression among HIV-positive patients. The other strength was the use of routine programme data that is always updated over time with information collected about all patients who were on ART in Kediri city without any exclusion. We collected data from the main e-database called System Informasi HIV AIDS (SIHA) which is the first/primary source of information on all HIV patients used across all the health centers and hospitals in Indonesia. These primary records are routinely audited by the Ministry of Health (Dinas Kesehatan) for its accuracy and consistency. Therefore, we strongly believe that the data collected in our study reflect what is happening in reality at this health center.

The main challenge/limitation in the study was that it was difficult to determine the total number of HIV-positive patients that need to test and confirm their HIV status. The other limitation was that the study methodology involved analysis of only secondary data of patient records in the SIHA database, and hence our analysis and interpretation of the data are limited to only those variables that are routinely collected from patients/care givers and captured in the patient records. Some of the important variables like 
height Medium Upper Arm circumference (MUAC) of the patient, HIV status of the other serodiscordant couples and so on, which could have played a major role in determining how other factors like Body Mass Index, Malnutrition influence viral load suppression in the HIV patients.

\section{Conclusion}

Kediri city is still far below the first and third 90 targets though almost closing the gap for the second 90 target. The most important target still remains the first target where the health center should identify all the possible people living with HIV mostly the key populations, have them tested for HIV and HIV-positive patients should immediately start on ART treatment as treatment is monitored through viral load testing and doing follow-ups for the lost patients. The fact that the time taken by the HIV-positive patient to start ART treatment from the time of confirmation being HIV positive and decrease in body weight was found to significantly influence viral load suppression in HIV-positive patients. The health centers in Kediri city should observe the recommended WHO and UNAIDS guidelines for HIV treatment (Test and Treat) so as to meet the 2020 90-90-90 UNAIDS target as well as the 2030 95-95-95 SDG target.

\section{Ethical Issues}

Ethical clearance and permission for the study were obtained from East Java Political and National Unity Agency (Bakesbangpol), Ministry of Health Kediri city in collaboration with the Faculty of Public Health Universitas Airlangga. Written informed consent was secured from the two key informants after explaining the objective of the study to each of the key informants. The patient consent to review their medical records by the researcher was not required by the approving agencies since the patients always sign a letter of informed consent at the start or ART treatment that their data may be used for further research but none of their identifying information say name and location will be retrieved. So, patients were only identified and linked using unique identification numbers. This study was conducted in accordance with the Declaration of Helsinki.

\section{Data Sharing Statement}

The data that supports the findings of this study are available from the corresponding author upon reasonable request.

\section{Acknowledgments}

The researchers would like to acknowledge and thank the HIV data staff at the respective health centers where the study was carried out; Imam Ma'ruf at Pesantren I Health Center, Niken Mardiyalina at Gambiran General Hospital and Dewi Irma at Semampir Health Center), the two key informants; Imam Ma'ruf, the health care provider in the HIV Unit at Pesantren 1 Health Center and Wisnu Satria Sejati, a member of the Peer Support Group of People Living with HIV-AIDS (PLWHA) in Kediri City for the time and their responses shared during the in-depth interviews to gather more information about HIV care at the health center and the general conditions for the HIVpositive patients.

\section{Funding}

The study did not get any financial support.

\section{Disclosure}

The authors declare no conflicts of interest in this study.

\section{References}

1. UNAIDS. UNAIDS 2016-2021 Strategy: on the Fast-Track to End AIDS. Geneva, Switzerland: UNAIDS; 2016. Available from: unaids. org. Accessed January 7, 2020.

2. UNAIDS. Fast-Track: Ending the AIDS Epidermic by 2030. Geneva, Switzerland: UNAIDS; 2014

3. UNAIDS. HIV Prevention 2020 Road Map. Geneva, Switzerland: UNAIDS; 2016. Available from: unaids.org. Accessed January 7, 2020.

4. World Health Organisation. World Health Organization. Progress Report on Prevent HIV, Test and Treat All. Geneva, Switzerland: World Health Organisation; 2016.

5. Das M, Chu PL, Santos G, Scheer S, Vittinghoff ECG. Decreases in community viral load are accompanied by reductions in new HIV infections in San Francisco. PLoS One. 2010;5:6. doi:10.1371/journal.pone. 0011068

6. UNAIDS. Understanding Fast Track; Accelerating Action to End the AIDS Epidemic by 2030. Geneva, Switzerland: UNAIDS; 2015. Available from: unaids.org. Accessed January 7, 2020

7. Croxford S, Kitching A, Desai S; GBD 2015 Eastern Mediterranean Region HIV/AIDS Collaborators. Mortality and causes of death in people diagnosed with HIV in the era of highly active antiretroviral therapy compared with the general population: an analysis of a national observational cohort. Lancet Public Health. 2017;2(1): e35-e46. doi:10.1016/S2468-2667(16)30020-2

8. UNAIDS. Ending AIDS Progress Towards the 90- 90-90targets. Geneva, Switzerland: UNAIDS; 2017. UNAIDS/JC2900E.

9. UNAIDS. The Need for Routine Viral Load Testing. Geneva, Switzerland: UNAIDS; 2016.

10. UNAIDS. HIV PREVENTION GAP REPORT. Geneva, Switzerland: UNAIDS; 2016. Available from: unaids.org. Accessed January 7, 2020.

11. UNAIDS. Fact Sheet - 2018 GLOBAL HIV STATISTICS 2019. Geneva, Switzerland: UNAIDS; 2019.

12. Kementerian Kesehatan Republik Indonesia. InfoDatin: Situasi Umum HIVIAIDS Dan Tes HIV. Jakarta: Kementerian Kesehatan Republik Indonesia; 2018. Indonesian.

13. UNAIDS. Tuberculosis and HIV-Progress Towards the 2020 Target. Geneva, Switzerland: UNAIDS; 2019. Available from: http://www. unaids.org/sites/default/files/media_asset/tuberculosis-and-hivprogress-towards-the-2020-target_en.pdf. Accessed January 7, 2020. 
14. UNAIDS. Global HIV Statistics 2018. Geneva, Switzerland: UNAIDS: 2019.

15. Kementerian Kesehatan RI Indonesia health profile, 2017. 2018. Available from: http://www.kemkes.go.id. Accessed January 7, 2020. Indonesian.

16. Globerman J, Gogolishvili DRS. Evidence Review: HIV Sexual Transmission Risk by People with Suppressed HIV Viral Load. Ontario HIV Treatment Network. Toronto; 2017.

17. Del Romero J, Castilla J, Hernando V, Rodríguez CGS. Combined antiretroviral treatment and heterosexual transmission of HIV-1: cross sectional and prospective cohort study. BMJ. 2010;340(7757):1179. doi:10.1136/bmj.c2205

18. Centers for Disease Control and Prevention. CDC Fact Sheet: Today's HIV/AIDS Epidemic. United States: Centers for Disease Control and Prevention; 2016.

19. Kementerian Kesehatan Republik Indonesia. Laporan Kineja Kementrian Kesehatan Tahun 2015. Jakarta: Kementerian Kesehatan Republik Indonesia; 2015. Indonesian.

20. Januraga PP, Reekie J, Mulyani T, et al. The cascade of HIV care among key populations in Indonesia: a prospective cohort study. Lancet HIV. 2018;5(10):e560-e568. doi:10.1016/S2352-3018(18)30148-6

21. Granich R, Gupta S, Wollmers M, Ruffner MWB. Modeling the HIV epidemic: why the 95- 95-95Target and ART effectiveness parameters matter. Int J Virol AIDS. 2018;5:1. doi:10.23937/2469-567x/1510041

22. Centers for Disease Control and Prevention. Evidence of HIV Treatment and Viral Suppression in Preventing the Sexual Transmission of HIV. United States: Centers for Disease Control and Prevention; 2018. Available from: https://www.cdc.gov/hiv/pdf/ risk/art/cdc-hiv-art-viral-suppression.pdf. Accessed January 14, 2020.

23. Arkell CHM. HIV Treatment and an Undetectable Viral Load to Prevent HIV Transmission FACT. Canadian AIDS Treatment Information Exchnage (CATIE). Toronto; 2018.

24. Bvochora T, Satyanarayana S, Takarinda KC, et al. Enhanced adherence counselling and viral load suppression in HIV seropositive patients with an initial high viral load in Harare, Zimbabwe: operational issues. PLoS One. 2019;14(2):1-13. doi:10.1371/journal.pone.0211326

25. World Health Organisation. Consolidated Guidelines on the Use of Antiretroviral Drugs for Treating and Preventing HIV Infection. Geneva, Switzerland: World Health Organization; 2013.

26. World Health Organisation. Consolidated Guidelines on the Use of Antiretroviral Drugs for Treating and Preventing HIV Infection; Recommendations for a Public Health Approach. 2nd. Geneva, Switzerland: World Health Organization; 2016.

27. Etoori D, Ciglenecki I, Ndlangamandla M, et al. Successes and challenges in optimizing the viral load cascade to improve antiretroviral therapy adherence and rationalize second-line switches in Swaziland. J Int AIDS Soc. 2018;21(10):1-8. doi:10.1002/jia2.25194

28. Rangarajan S, Colby DJ, Le Truong G, et al. Factors associated with HIV viral load suppression on antiretroviral therapy in Vietnam. J Virus Erad. 2016;2:94-101.

29. Huerga H, Van Cutsem G, Farhat JB, et al. Progress towards the UNAIDS 90- 90-90goals by age and gender in a rural area of KwaZulu-Natal, South Africa: a household-based community cross-sectional survey. BMC Public Health. 2018;18(1):4-11. doi:10.1186/s12889-018-5208-0

30. Saravanan S, Laeyendecker O, Balakrishnan P, et al. Community viral load, antiretroviral therapy coverage, and HIV incidence in India: a cross-sectional, comparative evaluation study. HHS Public Access. 2016;3(4):1-18. doi:10.1016/S2352-3018(16)00019-9.

31. Public Health Agency of Canada. Summary: Measuring Canada's Progress on the 90-90-90HIV Targets. Canada; 2016. Available from: https://www.canada.ca/content/dam/phac-aspc/documents/ser vices/publications/diseases-conditions/summary-measuring-canadaprogress-90-90-90-hiv-targets/hiv90-eng.pdf\%0Ahttps://www. canada.ca/content/dam/phac-aspc/documents/services/publications/ diseases-con. Accessed January 7, 2020.
32. O'Connor J, Smith C, Lampe FC, et al. Durability of viral suppression with first-line antiretroviral therapy in patients with HIV in the UK: an observational cohort study. Lancet HIV. 2017;4(7):e295e302. doi:10.1016/S2352-3018(17)30053-X

33. Lemeshow S, Hosmer DW, Klar JLS. Adequacy of Sample Size in Health Studies. Vol. 47. NY, USA: John Wiley \& Sons Ltd; 1991. doi: $10.2307 / 2532527$

34. UNAIDS. Global AIDS Monitoring 2019: Indicators for Monitoring the 2016 Political Declaration on Ending AIDS. Geneva, Switzerland: UNAIDS; 2019.

35. UNAIDS. Global AIDS Monitoring 2018: Indicators for Monitoring the 2016 United Nations Political Declaration on Ending AIDS. Geneva, Switzerland: UNAIDS; 2018. Available from: http://www.unaids.org/ sites/default/files/media asset/global-aids-monitoring en.pdf. Accessed January 7, 2020.

36. Kementerian Kesehatan Republic of Indonesia. Infodatin - situasi penyakit HIV AIDS di Indonesia: pusat data dan informasi Kementerian Kesehatan Republik Indonesia.Jakarta: Kementerian Kesehatan Republik Indonesia; 2016;c:2-6. Indonesian.

37. World Health Organisation. Guideline on When to Start Antiretroviral Therapy and on Pre-Exposure Prophylaxis for HIV: Potential Limitations of Earlier Initiation of Therapy. Geneva, Switzerland; 2015. Available from: http://www.ncbi.nlm.nih.gov/ books/NBK327118/. Accessed January 7, 2020.

38. Awungafa G, Amin ET, Fualefac A, et al. Viral load testing and the use of test results for clinical decision making for HIV treatment in Cameroon: an insight into the clinic-laboratory interface. PLoS One. 2018;13(6):3-7. doi:10.1371/journal.pone. 0198686

39. Bain LE, Nkoke CNJ. UNAIDS 90-90-90 targets to end the AIDS epidemic by 2020 are not realistic: comment on "Can the UNAIDS 90-90-90 target be achieved? A systematic analysis of national HIV treatment cascades". BMJ Glob Health. 2017;2(2):2016-2018. doi:10.1136/bmjgh-2016-000227

40. Ministry of Health Republic of Indonesia. HIV Epidemiology Review, Indonesia 2016. Jakarta: Kementerian Kesehatan Republik Indonesia; 2017.

41. Paudel T, Singh N, Banjara MR, Kafle SP, Ghimire YCPB. Epidemiology of HIV, programmatic progress and gaps in last 10 years in Nepal. $J$ Virus Erad. 2016;2(Supplement 4):35-40.

42. Hoenigl M, Chaillon A, Moore D, et al. Rapid HIV viral load suppression in those initiating antiretroviral therapy at first visit after HIV diagnosis. Sci Rep. 2016;6:1-5. doi:10.1038/srep32947

43. World Health Organisation. Guideline on When to Start Antiretroviral Therapy and on Pre-Exposure Prophylaxis for HIV. Geneva, Switzerland: World Health Organization; 2015.

44. Batavia AS, Secours R, Espinosa P, Juste MAJ, Severe P, Pape JWFD. Diagnosis of HIV-associated oral lesions in relation to early versus delayed antiretroviral therapy: results from the CIPRA HT001 trial. PLoS One. 2016;11(3):1-7. doi:10.1371/journal.pone.0150656

45. Sellers CJ, Wohl DA. Antiretroviral therapy: when to start. Infect Dis Clin North Am. 2014;28(3):403-420. doi:10.1016/j.idc.2014.05.004

46. Hoenigl M, Chaillon A, Little SJ. CD4/CD8 cell ratio in acute HIV infection and the impact of early antiretroviral therapy. Clin Infect Dis. 2016;63(3):425-426. doi:10.1093/cid/ciw293

47. Donnell D, Baeten JM, Kiarie J, et al. Heterosexual HIV-1 transmission after initiation of antiretroviral therapy: a prospective cohort analysis. Lancet. 2010;375(9731):2092-2098. doi:10.1016/S0140-6736(10)60705-2.

48. Mbengue M, Chasela C, Onoya D, Mboup S, Fox MED. Clinical predictor score to identify patients at risk of poor viral load suppression at six months on antiretroviral therapy: results from a prospective cohort study in Johannesburg, South Africa. Clin Epidemiol. 2019;11:359-373. doi:10.2147/CLEP.S197741

49. Li X, Ding H, Geng W, et al. Predictive effects of body mass index on immune reconstitution among HIV-infected HAART users in China. BMC Infect Dis. 2019;19(1):1-9. doi:10.1186/s12879-0193991-6 
50. Mwamburi DM, Wilson IB, Jacobson DL, et al. Understanding the role of HIV load in determining weight change in the era of highly active antiretroviral therapy. Clin Infect Dis. 2005;40(1):167-173. doi: $10.1086 / 426591$
51. Blashill AJ, Mayer KH, Crane HN, Grasso CSS. Body mass index, immune status and virological control in HIV-infected men who have sex with men. J Natl Inst Health. 2013;12(5):319-324. doi:10.1177/ 2325957413488182.Body

HIV/AIDS - Research and Palliative Care

\section{Publish your work in this journal}

HIV/AIDS - Research and Palliative Care is an international, peerreviewed open-access journal focusing on advances in research in HIV, its clinical progression and management options including antiviral treatment, palliative care and public healthcare policies to control viral spread. The manuscript management system is completely online and includes a very quick and fair peer-review system, which is all easy to use. Visit http://www.dovepress.com/testimonials.php to read real quotes from published authors. 